\title{
Impact of improved farm technology on pulses production in Karnataka
}

\author{
Vinayak S. Suragonda ${ }^{1}$, B. S. Reddy ${ }^{2 *}$ and O. P. Sharma ${ }^{3}$ \\ ${ }^{1}$ Department of Agricultural Economics, UAS, Raichur- 584104 (Karnataka), INDIA \\ ${ }^{2}$ College of Agriculture, Aland Road, Kalaburagi -585101 (Karnataka), INDIA \\ ${ }^{3}$ National Centre for Integrated Pest Management, IARI Campus, New Delhi-110012, INDIA \\ *Corresponding author. E-mail: bsreddyagecon@gmail.com
}

Received: January 13, 2016; Revised received: May 24, 2016; Accepted: August 05, 2016

\begin{abstract}
The current study aimed at evaluating technical efficiency and change in output of pulse crops in Karnataka. Totally 180 farmers were selected for eliciting required information on adoption of A3P technology. The results of the study revealed that majority of the farmers were operating above 80 per cent efficiency levels in both pulses across the farmers of A3P and Non-A3P. Further, more than 53 per cent of farmers' under redgram and 56 per cent under bengalgram have achieved 100 per cent efficiency level in A3P farmers category. Decomposition of the difference in total output between A3P and Non-A3P farmers was 13.23 and 14.86 per cent in redgram and bengalgram crops respectively. The A3P technology has alone contributed to the extent of 29 and 22 per cent to the total change in redgram and bengalgram output indicating output can be increased by about 29 and 22 per cent if the farmers could switch over from traditional practices (Non-A3P) to A3P technology. There is need to educate farmers on optimum use of inputs through conducting intensive trainings on A3P technology by KVK's and other extension agencies to increase the supply of pulses in the country.
\end{abstract}

Keywords: Bengalgram, Decomposition, Pulse crop, Redgram, Technical efficiency

\section{INTRODUCTION}

A majority of Indian population is vegetarian and pulses are playing important role in providing protein and other essential nutrients to the large population of the country. However, its area is fluctuating from year to year due to number of biotic and abiotic stresses, which are responsible for a large extent of the instability and low yields. With stagnant production of pulses, increasing dependence on imports and limited global supply of Kharif pulses, it was decided to boost the efforts under the ongoing National Food Security Mission by focusing on five key pulse crops viz; redgram, greengram, blackgram, bengalgram and lentil in major pulses growing states of the country (Sharma et al,2012).

India is the largest producer and consumer of pulses in the world contributing around 33 per cent of the world area and 25-28 per cent of world production of pulses. About 90 per cent of the global redgram, 75 per cent of bengalgram and 37 per cent of lentil area is contributed by India. The country produced 19.78 million tonnes of pulses from 17.21 million hectare area, with an average yield of $694 \mathrm{~kg}$ per hectare during 2013-14. These figures make India the largest producer of pulses in the world (Anonymous., 2012 a).

Karnataka is one of the important pulses growing state in the country. It is largely grown in the northern parts of the state especially in Kalaburagi district. Kalaburagi is one of the most important redgram growing district of Karna- taka occupying over an area of 3,40,119 hectare with the production of 2,50,736 tonnes $(53.68 \%$ ) of state redgram production. It has also produced 1, 29,137 tonnes of bengalgram from an area of 1, 58,987 hectare (Anonymous., 2012 b).

Government of India has initiated A3P under National Food Security Mission (NFSM) in the year 2010-11 for aggressive promotion of available technologies to all the farmers in identified 1,000 units of 1,000 hectare each. Kalaburagi is one of the district chosen among 1000 units of 1000 hectare selected for implementation of A3P in the country. Incentivized supply of kits of critical inputs containing plant nutrients and pesticides was made to the farmers under this program with assured extension support through contractual technical personnel in addition to existing extension staff at states and Government of India level. The objective of A3P are to demonstrate plant nutrient and plant protection centric improved technologies and management practices in compact blocks covering large area for five major pulse crops namely redgram, bengalgram, blackgram, greengram and lentils for increasing production and productivity of these crops. Apart from increasing the production and productivity of pulse crops by the participating farmers another objective of A3P is to stimulate other farmers in the adjoining areas to adopt these technologies to establish sustainability in the pulse production. These efforts are meant for long term goal to reduce malnutrition as well as ensuring nutritional security of marginal farmers (Sharma et al,2012). 
The current study aimed at evaluating technical efficiency and change in output of pulse crops in Karnataka.

\section{MATERIALS AND METHODS}

Kalaburagi district of Karnataka is purposively selected for the study wherein National Food Security Mission (NFSM) sponsored Accelerated Pulse Production Programme (A3P) was implemented during the period of 2010-11 to 2013-14.

The purposive random sampling technique was used to collect the required information from the sample farmers. In the first stage, Kalaburagi district was selected purposively, in the second stage three taluks namely Afzalpur, Aland and Chittapur were selected based on highest number of beneficiary received inputs and adopted technolyg under A3P project operated by Agricultural Research Station Kalaburagi. In the third stage, 40 farmers of A3P and 20 farmers of Non-A3P were selected from each taluk, were interviewed randomly to elicit the required information about redgram and bengalgram cultivation. Thus, total sample size of 180 farmers with 90 each in redgram (60 A3P farmers and 30 NonA3P farmers) and bengalgram(60 A3P farmers and 30 Non-A3P farmers) cultivars were chosen for the study.

For evaluating the objectives of the study, the required data is collected through personal interview method with the help of a well structured and pre-tested schedule. The data envelopment analysis is employed to study the technical efficiency level of the farmers and decomposition analysis is used to know the extent of difference in output contributed from the different resources used under redgram and bengalgram production.

Data envelopment analysis (DEA): Data Envelopment Analysis (DEA) is a Linear Programming methodology to measure the efficiency of multiple Decision Making Units (DMUs) when the production process presents a structure of multiple inputs and outputs. DEA is commonly used to evaluate the efficiency of a number of producers. A typical statistical approach is characterized as a central tendency approach and it evaluates producers relative to an average producer. In contrast, DEA is an extreme point method and compares each producer with only the "best" producers. By the way, in the DEA literature, a producer is usually referred to as a decision making unit or DMU. Extreme point methods are not always the right tool for a problem but are appropriate in certain cases.

DEA is a non parametric Linear programming approach to measure the efficiency of number of producers where as the Frontier production approach is a parametric approach. Since DEA is a deterministic approach it does not include the error component while Frontier analysis can be a stochastic approach and includes the random error term. The DEA method is a frontier method that does not require specification of a functional form or a distributional form, and can accommodate scale issues. DEA was applied by using both classic models CRS (constant re- turns to scale) and VRS (variable returns to scale) with input orientation, in which one seeks input minimization to obtain a particular product level. Under assumption of constant returns to scale, the linear programming models for measuring the efficiency of farmers (Coelli et al. 1998) were used.

Decomposition analysis: Technical change in the production function can be defined as a change in the parameters of the production function or creation of new production function. For any production function, the total change in output is brought about by the shifts in the parameters of production function and the changes in the volume of inputs. A rise in the total output under 'new' technology (A3P) over the 'old' technology (Non-A3P) with the use of same level of inputs can be attributed to the technical change. This change in total output due to technology is measured by changes in scale (intercept) and slope (elasticities) parameters. Out of this total change, shift in the intercept in equation measures the neutral component of the technical change and the shift in the slope parameters (ai and bi's) measure the nonneutral component of the technical change which together constitutes technological contribution to the difference in output under the 'A3P' and 'Non-A3P'redgram and bengalgram production technologies. Another contribution to the total output is due to the disequilibrium caused by new production relations. The total change in output due to adoption of $\mathrm{A} 3 \mathrm{P}$ technology is decomposed into the factors of technology and changes in the quantities of inputs. The output decomposition model as developed by Bisalaiah and used by Lalwani and Ganesh Kumar is used to decompose the difference in out put per acre between 'Non-A3P' and 'A3P' pulses production technologies into technical change and change in quantities of inputs used.

The output decomposition model developed by Bisaliah (1977) was used for investigating the percentage change in the yield between A3P and Non-A3P farmers and the factor contributes to the changes by estimates separate production functions.

\section{RESULTS AND DISCUSSION}

The table-1 indicated the technical efficiency of A3P and Non-A3P farmers in the redgram and bengalgram production. In case of redgram production, average technical efficiency in A3P farmers under CRS was 0.92 compared to Non-A3P farmers about 0.89 . Under the technology of programme at CRS more than 30 per cent of the farmers were cent per cent efficient in both $\mathrm{A} 3 \mathrm{P}$ and Non-A3P farmers. However, no farmers were operated below 60 per cent efficiency level. It is also clear from the table 1 that 53.33 per cent of A3P farmers were operated at 100 per cent efficiency level compared to 36.67 per cent of Non-A3P farmers. However only 5-6 per cent of the farmers were operated in the range of 60-70 per cent efficiency level and no one is operated below 60 per cent efficiency level mainly because of better management 


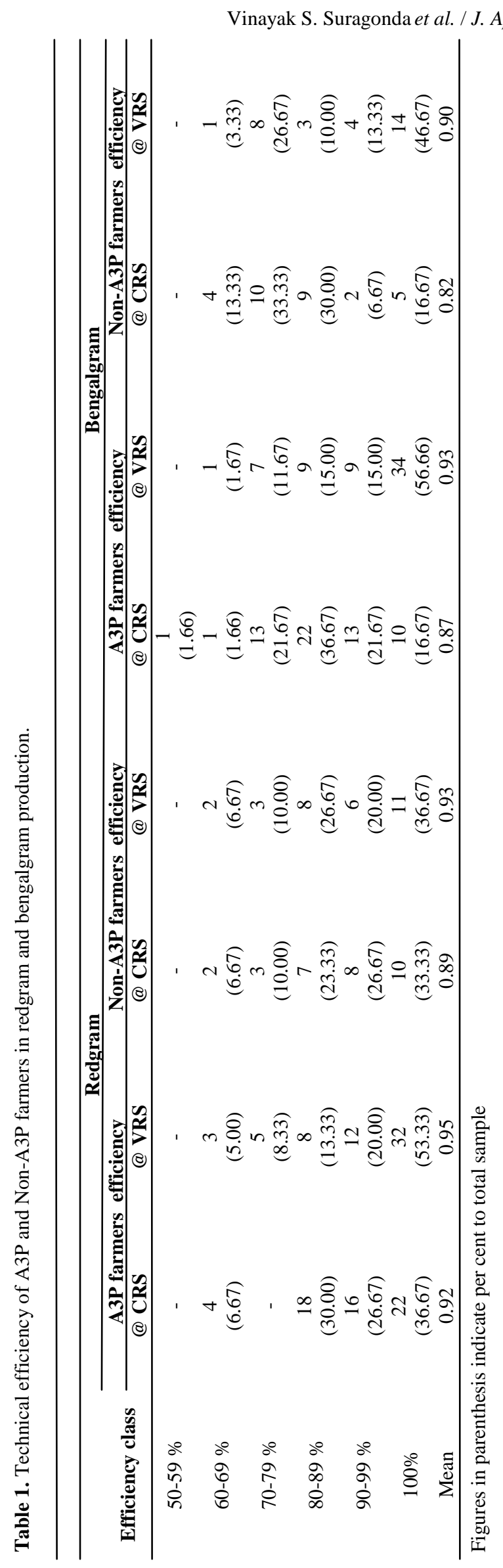

practices with intensive use of resources as per the advice of the scientist under A3P farms. Similar results were coated by Sharma et al.(2012) and Balappa Shivaraya and Hugar(2001). According to Sharma et al,(2012) who conducted study on performance of A3P technology in Karnataka revealed that A3P adopted farmers have achieved higher efficiency (85\%) compared to Non A3P (76.50\%) and also Balappa Shivaraya and Hugar(2001) conducted study on growth in efficiency and stability of onion production in Karnataka indicated that IPM adopted onion farmers have achieved higher efficiency than the Non-IPM onion producers.

The average technical efficiency of $\mathrm{A} 3 \mathrm{P}$ farmers of bengalgram cultivation under constant returns to scale was 0.87 compared to 0.82 in Non-A3P farmers. Under CRS, 16.67 per cent of farmers were more than 100 per cent technically efficient both in A3P and Non-A3P farmers of bengalgram producer. However, estimation of efficiency under VRS indicated that 56.66 per cent and 46.67 per cent farmers under A3P and Non-A3P respectively were 100 per cent technically efficient in utilizing available resources for bengalgram production. The study conducted by Savita Patil et. al. (2012) on efficiency of paddy farms in India indicated that majority of the farmers were operating in medium efficiency level (70\%) followed by low efficiency level (17\%) and high efficiency (23\%) level with respect use of nitrogen and PP Chemicals. Therefore majority of the $\mathrm{A} 3 \mathrm{P}$ farmers were operated under high scale efficiency and there is a need to improve the technical efficiency of remaining farmers to achieve higher technical efficiency through adoption of modern technologies like IPM, INM, etc.

The decomposition analysis (table-2) revealed that, the farmers following A3P method produced 13.23 per cent higher output than that of Non-A3P practice of redgram production. The increase in output was further decomposed into different sources of change such as adoption of A3P method and use of all other inputs. The A3P method alone contributed to the tune of 13.23 per cent increase in the output, while the contribution of change in input levels was found to be negative $(-15.49 \%)$. Amongst various inputs, seeds $(7.39 \%)$, plant protection chemicals (5.39\%), and fertilizer $(1.73 \%)$ contributed positively, whereas, land (-25.03\%), bullock labour (-1.97\%), farm yard manure $(-2.77 \%)$ and human labour $(-0.22 \%)$ contributed negatively to the total redgram output. In other words, excess use of land, bullock labour, human labour and farm yard manure contributed negatively for increase in redgram output. Similar results were reported by Balappa Shivaraya, et.al. (1998) conducted study on resource use efficiency in redgram under IPM technology in Gulbarga district indicating IPM adopted farmers have obtained higher yield with higher efficiency compare to Non-IPM farmers with lower efficiency.

In case of bengalgram production, the total growth in bengalgram output was 14.86 per cent higher under A3P famers than that of Non-A3P farmers. The increase in 
Vinayak S. Suragonda et al. / J. Appl. \& Nat. Sci. 8 (3): 1471 - 1474 (2016)

Table 2. Decomposition of redgram and bengalgram output between A3P and Non-A3P farmers.

\begin{tabular}{clcc}
\hline Sl. No. & \multicolumn{1}{c}{ Particulars } & Redgram $(\boldsymbol{\%})$ & Bengalgram $(\boldsymbol{\%})$ \\
\hline I & Total observed difference in output & 13.23 & 14.86 \\
II & Source of output growth & & 22.00 \\
1 & Technology component & 29.00 & -149.90 \\
A & Neutral component & -21.69 & 171.76 \\
B & Non-Neutral component & 50.41 & -7.00 \\
2 & Input contribution & -15.49 & -3.60 \\
A & Land & -25.03 & 0.23 \\
B & Seeds & 7.39 & 1.49 \\
C & Human labour & -0.22 & -4.42 \\
D & Bullock labour & -1.97 & -2.34 \\
E & FYM & -2.77 & 0.13 \\
F & Fertilizer & 1.73 & 1.51 \\
G & PPC & 5.39 & 14.86 \\
III & Total Estimated difference in output & 13.23 & \\
\hline
\end{tabular}

output was further decomposed into different sources of change i.e. adoption of A3P and use of inputs. The A3P technology adopted farmers alone contributed to the extent of 22 per cent increase in bengalgram output, while the contribution of change in input use levels were found to be negative $(-7 \%)$. Amongst various inputs, seeds $(0.23$ $\%)$, human labour $(1.49 \%)$, plant protection chemicals $(1.51 \%)$, and fertilizer $(0.13 \%)$ contributed positively, whereas, land $(-3.60 \%)$, bullock labour $(-4.42 \%)$ and farm yard manure $(-2.34 \%)$ contributed negatively to the total bengalgram output. An increase in output excessively from technological improvement is brought about through shift in the scale or slope parameters of the production function. Improved practices, high quality resources viz., land, seeds, farm yard manure, fertilizers and plant protection chemicals used in $\mathrm{A} 3 \mathrm{P}$ practices of pulse production has helped to increase output of the A3P farmers. The study conducted by Priyanka et al. (2013) indicated that output elasticity of seeds, human labour and irrigation in transplanted $(0.25,0.80$ and 0.05$)$ and dibbled Method $(0.11,0.44$ and 0.18$)$ were positive and significant, which were influenced significantly on gross returns in redgram production under both transplanted and dibbled methods.

\section{Conclusion}

The mean efficiency of 0.95 and 0.93 in redgram and bengalgram production at the variable returns to scale implied decreasing returns to scale in A3P farmers. Similar trend of returns to scale was noticed in Non-A3P farmers. The decomposition of the difference in total output between A3P and Non-A3P farmers was 31.25 per cent. The A3P technology has alone contributed to the extent of 29.40 per cent to the total change in output while the contribution of all other inputs used were found to be only 1.84 per cent indicating pulse output can be increased by about 29.40 per cent if the farmers could switch over from the traditional practices (Non-A3P) to A3P technology. However among the inputs, seeds, fertilizers and plant protection chemicals were contributed positively and other inputs were contributed negatively. There is need to educate farmers on optimum use of inputs through conducting intensive trainings on A3P technology by KVK's and also through conducting field days and demonstration by farm universities and developmental departments. These findings will serve as a important input into policy making particularly to bridge the gap between demand and supply of pulses in the country.

\section{REFERENCES}

Anonymous (2012a).Vision 2030. Indian Institute of Pulse Research Report., Kanpur, pp11-15.

Anonymous (2012b). Final advance estimates of area, production and yield of important agricultural crops in Karnataka 2011-12, DES Report :74-94.

Balappa Shivaraya, Hugar, L. B. and Hiremath, G.K. (1998). Resource use efficiency in red gram under integrated pest management technology in Gulbarga district. Karnataka J. Agric. Sci., 11(3): 712-716.

Balappa Shivaraya, and Hugar, L. B., (2001). Growth in efficiency and instability of onion production in Karnataka. Plant Horti Tech, 2(6):48-49.

Bisaliah, S.,(1977). Decomposition analysis of output change under new production technology in wheat farming. Indian J. Agric. Econ., 23(3): 193-201.

Coelli, T. J., (1998). Recent development in frontier modeling of efficiency. Australian J. of Agric. Econ., 39(3): 219-245.

Priyanka, K., Patil, S. S., Hiremath, G. M., Amrutha. T. J. and Sunil, K. A., (2013). Comparative analysis of transplanted and dibbled method of redgram cultivation in Bidar district of Karnataka. Karnataka J. Agric. Sci., 26 (2): 238-242.

Savita K. Patil, Hugar, L.B. and Reddy, B.S., (2012). Efficiency of Paddy Farms in India: An Empirical Evidence of TBP Area of Karnataka state. J. of Econ. and Sustainable Devt. 3(6):43-52.

Sharma, O. P., Bambawale, O. M., Yelshetty, S., Patil, B.V., Gopali, J.B., Bhagat, S., Khullar, M., Neeraja, A., Rachappa V. and Patil V.M., (2012), Innovative approach in sustainable production of pigeonpea and chickpea. NCIPM Publication report.,: 11-55. 